\title{
Mitigasi Risiko Dalam Pembacaan Dan Penandatanganan Akta (Studi Penghadap yang Tidak Datang Bersamaan ke Hadapan Notaris)
}

\author{
Rizka Nurmadany \\ Magister Kenotariatan Fakultas Hukum Universitas Islam Indonesia Yogyakarta Indonesia \\ Jln. Cik Di Tiro No. 1 Yogyakarta Indonesia \\ rizkanurmadany@gmail.com
}

\begin{tabular}{|c|c|}
\hline Key Word: & Abstract \\
\hline $\begin{array}{l}\text { Authentic deed; } \\
\text { notary position; risk } \\
\text { mitigation }\end{array}$ & $\begin{array}{l}\text { This study aims to analyze the validity of the Notary's deed and the legal } \\
\text { consequences related to the applicants who are not present before the Notary and to } \\
\text { analyze the risk mitigation for the applicants who are not present at the same time } \\
\text { before the Notary at the time of reading and signing the deed. This research is a } \\
\text { normative legal research. The results of the study conclude that the reading and } \\
\text { signing the deed that is not carried out before a Notary will result in a decrease in } \\
\text { the evidenciary value of an authentic deed into a private deed as stated in Article } 16 \\
\text { paragraph (9) of Law Number } 2 \text { of } 2014 \text { and violates the provisions of Article } 4 \\
\text { paragraph (6) of the Indonesian Notary Association's Code of Ethics which renders } \\
\text { the consequences in the form of sanctions. In the case of a Notary deed not being } \\
\text { read and signed jointly because one of the parties, namely the bank, was not present } \\
\text { and only sent a copy of the deed to be signed later, it is certainly contrary to the } \\
\text { provisions of Law Number } 2 \text { of } 2014 \text { and the Notary Code of Ethics which of course } \\
\text { will has legal implications for both the deed and the Notary concerned. }\end{array}$ \\
\hline
\end{tabular}

Kata-kata Kunci:

Akta otentik; jabatan notaris; mitigasi risiko

\begin{abstract}
Abstrak
Penelitian ini bertujuan untuk menganalisis keabsahan akta Notaris dan akibat hukum terkait penghadap yang tidak hadir di hadapan Notaris dan menganalisis mitigasi risiko bagi penghadap yang tidak hadir secara bersamaan di hadapan Notaris pada saat pembacaan dan penandatanganan akta. Penelitian ini adalah penelitian hukum normatif. Hasil penelitian menyimpulkan pembacaan dan penandatanganan akta yang tidak dilakukan di hadapan Notaris akan berakibat turunnya nilai pembuktian akta otentik menjadi akta di bawah tangan sebagaimana tertuang dalam Pasal 16 ayat (9) Undang-Undang Nomor 2 Tahun 2014 dan melanggar ketentuan Pasal 4 ayat (6) Kode Etik Ikatan Notaris Indonesia yang menimbulkan konsekuensi berupa sanksi. Dalam kasus akta Notaris tidak dibacakan dan ditandatangani secara bersama-sama yang dikarenakan salah satu pihak yakni pihak perbankan tidak hadir dan hanya dikirimkan salinan akta untuk kemudian ditandatangani sudah tentu bertentangan dengan ketentuan Undang-Undang Nomor 2 Tahun 2014 dan Kode Etik Notaris yang sudah tentu akan berimplikasi hukum baik terhadap akta tersebut maupun Notaris yang bersangkutan.
\end{abstract}

\section{Pendahuluan}

Notaris adalah pejabat umum yang secara khusus diberikan wewenang oleh undang-undang untuk membuat suatu alat bukti yang otentik (mempunyai kekuatan pembuktian yang sempurna). Alat bukti tertulis yang bersifat otentik dibutuhkan untuk 
menjamin kepastian, ketertiban, dan perlindungan hukum. ${ }^{1}$ Alat bukti tertulis yang bersifat otentik ini berfungsi untuk menciptakan keseimbangan dan keteraturan (ordered) dalam sebuah hubungan hukum, yaitu bagaimanakah hubungan hukumnya, apa yang menjadi perbuatan hukumnya, dan mengapa terjadi suatu peristiwa hukum (rechtsfeiten). ${ }^{2}$

Pasal 1868 KUHPerdata menegaskan bahwa suatu akta otentik ialah suatu akta yang dibuat dalam bentuk yang ditentukan undang-undang oleh atau dihadapan pejabat umum yang berwenang untuk itu di tempat akta itu dibuat. Pasal 1868 KUHPerdata kemudian menegaskan unsur dan syarat yang harus dipenuhi dalam pembuatan akta otentik yakni:

1. akta itu harus dibuat dalam bentuk yang ditentukan oleh undang-undang;

2. akta harus dibuat oleh (door) atau di hadapan (ten overstaan) seorang pejabat umum;4

3. akta itu dibuat oleh atau di hadapan pejabat umum yang berwenang atau membuatnya di tempat di mana akta itu dibuat. ${ }^{5}$

Notaris sebagai pejabat umum diangkat oleh pemerintah untuk kepentingan masyarakat luas. Jasa yang diberikan oleh Notaris terkait erat dengan persoalan trust (kepercayaan antara para pihak). Pemberian kepercayaan kepada Notaris berarti Notaris tersebut mau tidak mau telah dapat dikatakan memikul pula tanggungjawab berupa tanggungjawab secara hukum maupun moral. ${ }^{6}$

Notaris merupakan suatu jabatan di bidang hukum yang terkait erat dengan pembuatan alat bukti berupa akta. Pemerintah Hindia Belanda pada 1860 memandang perlu untuk membuat peraturan yang mengatur mengenai jabatan Notaris di Nederlands Indie untuk disesuaikan dengan peraturan mengenai jabatan Notaris yang berlaku di Belanda. Keberadaannya di nusantara sejak zaman kolonial Belanda mendasarkan pada Reglement op Het Notaris Ambt in Indonesie (Stb. 1860 No.3).7

Peraturan kolonial Belanda ini berlangsung hingga masa kemerdekaan Indonesia yaitu dengan diundangkannya Undang-Undang Nomor 30 Tahun 2004 tentang Jabatan Notaris yang telah diubah dengan Undang-Undang Nomor 2 Tahun 2014 (selanjutnya disebut UUJN). ${ }^{8}$ Semenjak Indonesia merdeka, lembaga Notariat terus digunakan oleh

\footnotetext{
${ }^{1}$ Muhammad Luthfan Hadi Darus, Hukum Notariat dan Tanggungjawab Jabatan Notaris, Cetakan Pertama, UII Press, Yogyakarta, 2017, hlm. 1.

${ }^{2}$ Agus Pandoman, Teori dan Praktik. Akta; Perikatan Publisitas dan Non-Publisitas, Cetakan Pertama, PT. Raga Utama Kreasi, Yogyakarta, 2017, hlm. 15.

3 Pasal 38 Undang-Undang No 30 Tahun 2004 tentang Jabatan Notaris sebagaimana diubah dengan Undang-Undang No 2 Tahun 2014

${ }^{4}$ Pejabat Umum yang dimaksud antara lain Notaris, seorang Hakim, Panitera, seorang Juru Sita pada suatu pengadilan, seorang pegawai catatan sipil dan sebagainya. Dengan demikian maka suatu akta Notaris, suatu surat putusan Hakim, suatu surat proses verbal yang dibuat oleh seorang Juru Sita pengadilan dan akta perkawinan, akta kelahiran, akta kematian yang dibuat oleh Pegawai Catatn Sipil adalah akta otentik.

5Pengertian berwenang di sini meliputi berwenang terhadap orangnya, berwenang terhadap aktanya, berwenang terhadap waktunya, berwenang terhadap tempatnya.

${ }^{6}$ Abdul Ghofur Anshori, Lembaga Kenotariatan Indonesia; Perspektif Hukum dan Etika, Cetakan Pertama UII Press, Yogyakarta, 2009, hlm. 43.

${ }^{7}$ Stb. 1860 No. 3 diundangkan untuk menggantikan aturan sebelumnya yakni Stb. No. 11.

${ }^{8}$ Abdul Ghofur Anshori, Op. Cit., hlm. 101.
} 
masyarakat dan menjadi lembaga hukum Indonesia, dimanfaatkan oleh semua golongan. ${ }^{9}$

Keberadaan Notaris dalam kebutuhan akan suatu alat bukti otentik juga dirasakan dalam industri perbankan di Indonesia. Salah satu produk dari perbankan adalah kredit, yang dituangkan dalam bentuk perjanjian kredit. Perjanjian kredit yang dituangkan dalam bentuk akta otentik membutuhkan peran Notaris dalam proses pembuatannya.

Membacakan akta sampai pada penandatangan adalah satu kesatuan dari peresmian akta, dimana sebelum akta tersebut ditandatangani, terlebih dahulu akta tersebut dibacakan di depan para pihak yang bersangkutan guna menyampaikan isi akta dengan keinginan para pihak kemudian akta tersebut ditandatangani tentunya di hadapan para pihak dan 2 orang saksi. Ketentuan Pasal 16 ayat (1) huruf m UUJN tersebut adalah kewajiban Notaris, dan kata di hadapan adalah hadirnya Notaris secara fisik di hadapan para pihak dan saksi-saksi. Hal yang demikian selaras dengan pelaksanaan asas kehati-hatian bagi Notaris dalam menjalankan tugas jabatannya.

Meneliti semua kelengkapan dan keabsahan alat bukti atau dokumen yang diperlihatkan kepada Notaris, serta mendengar keterangan atau pernyataan para penghadap wajib dilakukan sebagai dasar pertimbangan untuk dituangkan di dalam akta. Apabila Notaris kurang teliti dalam memeriksa fakta-fakta penting, itu berarti Notaris bertindak tidak hati-hati. Asas kehati-hatian adalah suatu asas yang menyatakan bahwa Notaris dalam menjalankan fungsi dan jabatannya wajib menerapkan prinsip kehati-hatian dalam rangka melindungi kepentingan masyarakat yang dipercayakan padanya. Tujuan diberlakunya prinsip kehati-hatian tidak lain adalah agar Notaris selalu dalam rambu-rambu yang benar.

Kejadian dalam praktik Notaris, pernah terjadi seorang Notaris dilaporkan oleh salah satu pihak yang namanya tersebut dalam akta, bahwa dirinya tidak menghadap pada jam/pukul yang tersebut dalam awal akta, tapi menghadap 4 jam kemudian dari penghadap sebelumnya. Sengketa tersebut awalnya tidak berkaitan dari akta Notaris, tapi karena salah satu pihak ada yang merasa dirugikan dari substansi akta yang dikehendaki oleh para penghadap sendiri, sehingga merambat kepada prosedur pembuatan akta, dan pihak yang melaporkan kepada yang berwajib tersebut dapat membuktikan bahwa dirinya pada jam/pukul yang tersebut dalam awal akta tidak menghadap. Tapi yang menghadap tersebut penghadap yang awal/pertama datang.

Hal demikian dapat membuat Notaris turut terlibat dalam gugatan hukum dan tentu akan menjadi beban bagi Notaris yang bersangkutan. Sehingga, Penulis menganggap perlu untuk mengkaji keabsahan dan akibat hukum akta Notaris terkait penghadap yang tidak hadir di hadapan Notaris. Selain itu perlu pula untuk dikaji aspek mitigasi risiko yang dapat dilakukan oleh Notaris untuk mencegah terjadinya permasalahan hukum di kemudian hari apabila para penghadap tidak datang bersamasama pada saat proses pembacaan dan penandatanganan akta. Bagi Penulis, hal yang demikian penting demi eksistensi dan perkembangan dunia Notaris di Indonesia.

${ }^{9}$ R. Soegondo Notosoedirjo, Hukum Notariat di Indonesia; Suatu Penjelasan, PT. RajaGrafindo Persada, Jakarta, 1993, hlm. 4. 


\section{Rumusan Masalah}

Berdasarkan uraian latar belakang tersebut, rumusan masalah dalam penelitian ini yakni, pertama, bagaimana keabsahan dan akibat hukum akta Notaris terkait penghadap yang tidak hadir di hadapan Notaris? Kedua, bagaimana mitigasi risiko bagi penghadap yang tidak hadir secara bersamaan di hadapan Notaris pada saat pembacaan dan penandatanganan akta?

\section{Tujuan Penelitian}

Tujuan yang hendak dicapai melalui penelitian ini adalah untuk, pertama, menganalisis keabsahan dan akibat hukum akta Notaris terkait penghadap yang tidak hadir di hadapan Notaris. Kedua, menganalisis mitigasi risiko bagi penghadap yang tidak hadir secara bersamaan di hadapan Notaris pada saat pembacaan dan penandatanganan akta.

\section{Metode Penelitian}

Penelitian ini adalah penelitian hukum normatif karena yang diteliti adalah normanorma hukum yang terkait dengan keabsahan dan akibat hukum akta noratis serta mitigasi risiko penghadap yang tidak datang bersamaan ke hadapan Notaris pada saat pembacaan dan penandatanganan akta. Metode pendekatan yang digunakan adalah pendekatan perundang-undangan. Bahan hukum yang digunakan adalah. Pertama, bahan hukum primer, meliputi Kitab Undang-Undang Hukum Perdata, Undang-Undang Nomor 2 Tahun 2014 tentang Perubahan Atas Undang-Undang Nomor 30 Tahun 2004 tentang Jabatan Notaris, dan peraturan perundang-undangan lainnya yang terkait dengan penelitian ini. Kedua, bahan sekunder terdiri dari buku yang berkaitan dengan dengan mitigasi risiko penghadap yang tidak datang bersamaan ke hadapan Notaris pada saat pembacaan dan penandatanganan akta. Pengumpulan bahan hukum menggunakan studi pustaka dan studi dokumen. Analisis data yang digunakan adalah analisis data kualitatif.

\section{Hasil Penelitian dan Pembahasan}

\section{Keabsahan dan Akibat Hukum Akta Notaris terkait Penghadap yang Tidak Hadir di Hadapan Notaris}

Akta Notaris dapat dikatakan sebagai suatu akta otentik atau akta yang memiliki kekuatan pembuktian yang sempurna wajib untuk memenuhi unsur formil (bentuk) maupun materiil (isinya), sehingga Notaris dalam menyiapkan akta wajib untuk memperhatikan prosedur serta kebenaran dari isi akta tersebut. Keberadaan akta Notaris yang merupakan suatu akta otentik sangat penting, khususnya bagi pihak-pihak yang memerlukan suatu alat bukti yang sempurna terkait dengan perbuatan hukum yang mereka lakukan. Alat bukti yang sah atau diterima dalam suatu perkara (perdata) pada dasarnya terdiri dari ucapan dalam bentuk keterangan saksi, pengakuan, serta sumpah dan tertulis dapat berupa tulisan-tulisan yang mempunyai nilai pembuktian. ${ }^{10}$

${ }^{10}$ George Whitecross Patton, A Text-Book of Jurisprudence, Clarendon Press, Oxford, 1953, hlm. 481. 
Selain memastikan terpenuhinya unsur formil (bentuk) dalam akta yang dibuatnya, Notaris juga wajib untuk memastikan terpenuhinya unsur materiil (isi) dari akta yang dibuatnya. Unsur materiil yang pertama berupa objek yang tertentu (clear definite) yang diperjanjikan. Menurut Pasal 1332 dan 1334 KUHPerdata, hanya barang-barang yang dapat diperdagangkan saja dapat menjadi pokok perjanjian, tidak perduli apakah barang-barang itu sudah ada atau yang baru akan ada.

Prestasi tersebut hanya mengikat pihak-pihak tersebut dalam akta, ketentuan ini sebagaimana tersebut dalam Pasal 1340 KUHPerdata, yaitu, "suatu perjanjian hanya berlaku antara pihak yang membuatnya. Suatu perjanjian tidak dapat membawa rugi kepada pihak-pihak ketiga, tak dapat pihak-pihak ketiga mendapat manfaat karenanya, selain dalam yang diatur dalam Pasal 1317 KUHPerdata". Unsur materil yang kedua adalah sesuatu yang diperbolehkan,11 baik menurut undang-undang, kebiasaan, kepatutan, kesusilaan, dan ketertiban umum yang berlaku pada saat perjanjian dibuat dan ketika akan dilaksanakan.

Menurut Nurhadi Darussalam, selaku Notaris werda dan mantan Majelis Pengawas Wilayah Provinsi Daerah Istimewa Yogyakarta selama 3 periode mengatakan bahwa, masih adanya Notaris yang tetap melaksanakan pembacaan dan penandatanganan akta tidak di hadapan seluruh para pihak merupakan sesuatu yang dianggap lazim dan terkesan ada pembiaran, khususnya terhadap Notaris yang menjadi rekanan bank. Seharusnya hal tersebut tidak terjadi sebab jelas-jelas melanggar ketentuan UUJN dan Kode Etik Ikatan Notaris Indonesia. ${ }^{12}$

Dalam hal ini Notaris harus dapat menegakkan dan menerapkan spirit pelaksanaan tugas jabatan Notaris yang baik, mempunyai kredibilitas sehingga tidak dikontrol oleh bank-bank rekanan, juga perlunya sinergisitas antara pengurus Ikatan Notaris Indonesia dengan pihak-pihak dari bank yang menjadi rekanan Notaris agar dapat berjalan beriringan tanpa melakukan pelanggaran aturan. ${ }^{13}$

Notaris yang bersangkutan apabila menyadari akan tugas dan kewenangannya serta jabatan yang diemban, sudah seharusnya Notaris menolak untuk mengikuti kehendak dari pihak bank yang meminta minuta akta yang telah dibacakan dan ditandatangani oleh Notaris dan nasabah untuk dikirim ke bank untuk selanjutnya ditandatangani sebab hal tersebut jelas bertentangan terhadap ketentuan UUJN dan Kode Etik Notaris yang akan berimplikasi hukum bagi Notaris itu sendiri di kemudian hari. Notaris harus juga menyadari bahwa produk aktanya dimaknai sebagai upaya negara untuk menciptakan kepastian dan perlindungan hukum bagi masyarakat. Mengingat dalam wilayah hukum privat, negara menempatkan Notaris sebagai pejabat umum yang berwenang dalam hal pembuatan akta otentik, yaitu salah satunya untuk kepentingan pembuktian/alat bukti.

\footnotetext{
${ }^{11}$ Suatu persetujuan tanpa sebab, atau yang telah dibuuat karena sesuatu sebab yang palsu atau terlarang, maka persetujuan tersebut tidak mempunyai kekuatan (Pasal 1335 KUHPerdata). Jika tidak dinyatakan suatu sebab, tetapi ada sebab yang halal (tidak dilarang), ataupun jika ada suatu sebab lain daripada yang dinyatakan maka persetujuan tetap sah (Pasal 1336 KUHPerdata).

${ }^{12}$ Hasil wawancara dengan Nurhadi Darussalam Notaris/PPAT di Kabupaten Sleman, Majelis Pengawas Notaris Provinsi Daerah Istimewa Yogyakarta periode 2010-2019, serta akademisi di Universitas Islam Indonesia dan Universitas Gadjah Mada, 9 Mei 2020.

${ }^{13}$ Ibid.
} 
Kewajiban Notaris untuk membacakan akta di hadapan penghadap dengan dihadiri oleh paling sedikit 2 orang saksi dan ditandatangani pada saat itu juga oleh penghadap, saksi, dan Notaris diatur dalam Ketentuan Pasal 16 ayat (1) huruf 1 UUJN. Ketentuan ini dipertegas kembali dalam Pasal 44 UUJN yang menyatakan bahwa segera setelah akta dibacakan, akta tersebut ditandatangani oleh setiap penghadap, saksi, dan Notaris, kecuali apabila ada penghadap yang tidak dapat membubuhkan tanda tangan dengan menyebutkan alasannya. Ketentuan pembacaan dan penandatanganan tersebut adalah satu kesatuan dari peresmian akta (verlijden).

Kata "di hadapan" dalam penandatanganan akta tersebut adalah hadirnya seorang Notaris dalam proses peresmian akta (verlidjen) atau face to face sebagaimana diatur dalam penjelasan Pasal 16 ayat (1) huruf m UUJN. Saat praktik penandatanganan akta dimana dalam penandatanganannya tidak dilakukan di hadapan para pihak dan saksi-saksi ketika pembuatan akta pembebanan tersebut terjadi secara bersamaan pada tempat yang berbeda.

Pembacaan dan penandatanganan akta yang tidak dilakukan di hadapan Notaris akan berakibat turunnya nilai pembuktian akta otentik menjadi akta di bawah tangan sebagaimana tertuang dalam Pasal 16 ayat (8) UUJN. Pasal 16 ayat (9) UUJN mengatur jika salah satu syarat sebagaimana dimaksud pada ayat (1) huruf $m$ dan ayat (7) tidak terpenuhui, akta yang bersangkutan hanya mempunyai kekuatan pembuktian sebagaimana akta di bawah tangan. Akta Notaris mempunyai kekuatan pembuktian sebagai akta di bawah tangan dapat berakibat dituntutnya Notaris untuk melakukan penggantian biaya, ganti rugi dan bunga. Ketentuan Pasal 52 ayat (3) UUJN yang menegaskan bahwa akibat akta yang mempunyai kekuatan pembuktian sebagai akta di bawah tangan maka Notaris wajib membayar biaya, ganti rugi dan bunga.

Pembacaan dan penandatangan akta yang tidak dilakukan di hadapan Notaris juga dapat dikualifikasikan sebagai suatu pelanggaran terhadap Pasal 4 ayat (6) Kode Etik Ikatan Notaris Indonesia, yakni yang menyebutkan bahwa, "Notaris dilarang untuk mengirimkan minuta kepada klien untuk ditandatangani." Pelanggaran terhadap ketentuan tersebut juga akan menimbulkan sanksi bagi Notaris, yakni berupa sanksi administratif yang diatur dalam Pasal 6 ayat (1) Kode Etik Ikatan Notaris Indonesia. Sanksi yang dikenakan terhadap anggota (dalam hal ini Notaris) yang melakukan pelanggaran kode etik, yakni berupa teguran, peringatan, schorsing (pemecatan sementara) dari keanggotaan perkumpulan, onzetting (pemecatan) dari keanggotaan perkumpulan, dan pemberhentian dengan tidak hormat dari keanggotaan perkumpulan.

Penurunan status kekuatan alat bukti akta Notaris dapat terjadi apabila dalam pembuatannya terjadi pelanggaran terhadap ketentuan persyaratan hukum yang berlaku. Salah satu bentuk pelanggaran tersebut adalah membuat akta-akta yang tidak sesuai dengan fakta. Kemudian, yang sangat sering terjadi dan menjadi perhatian penulis ialah terkait dengan tidak dibacakannya akta dan penandatanganan akta yang tidak dilakukan Notaris di hadapan penghadap (klien) secara bersama-sama. Selain itu, tidak dipenuhinya syarat-syarat yang sudah ditentukan menurut hukum juga dapat menyebabkan akta Notaris menjadi batal demi hukum.

Akta Notaris sebagai alat bukti, agar dapat mempunyai kekuatan pembuktian yang sempurna jika seluruh ketentuan prosedur atau tata cara pembuatan akta tersebut 
dipenuhi. Jika ada prosedur yang tidak dipenuhi dan prosedur yang tidak dipenuhi tersebut dapat dibuktikan, maka akta tersebut dengan proses pengadilan dapat dinyatakan sebagai akta yang mempunyai kekuatan pembuktian sebagai akta di bawah tangan. Jika sudah berkedudukan seperti itu, maka nilai pembuktiannya diserahkan kepada hakim. ${ }^{14}$

Pembacaan akta sebagaimana dimaksud pada Pasal 16 ayat (1) huruf m UUJN tidak wajib dilakukan jika penghadap menghendaki agar akta tidak dibacakan karena penghadap telah membaca sendiri, mengetahui dan memahami isinya, dengan ketentuan bahwa hal tersebut dinyatakan dalam penutup akta serta pada setiap halaman minuta akta diparaf oleh penghadap, saksi dan Notaris.

\section{Mitigasi Risiko bagi Penghadap yang Tidak Hadir Secara Bersamaan di Hadapan Notaris pada Saat Pembacaan dan Penanda Tanganan Akta}

Berdasarkan uraian sebelumnya, timbul suatu pertanyaan, apakah ada mitigasi risiko demi tetap menjaga keotentikan akta yang tidak dibacakan bersama-sama terhadap seluruh penghadap mengingat realita yang sudah sering terjadi bahwa karena kesibukan dari pihak perwakilan bank ataupun efisiensi waktu sehingga menyebabkan ketidakhadiran dari pihak bank pada saat proses pembacaan dan penandatanganan akta oleh Notaris? Hal yang demikian yang dilakukan oleh Notaris, yakni tidak membacakan akta secara bersama-sama di hadapan seluruh penghadap terlarang untuk dilakukan atau sesuatu yang tidak dilarang sepanjang ada alasannya atau dicari solusi lain yang sesuai dengan perkembangan dunia Notaris.

Mitigasi risiko dalam hal ini yaitu telah dipersiapkan (back up) upaya hukum jika penghadap tidak datang bersama-sama (secara bersamaan) tersebut dipermasalahkan oleh para penghadap atau oleh pihak lainnya. Apakah dimungkinkan jika terjadi seperti itu, Notaris meminta kepada para penghadap jika tidak datang secara bersamaan untuk meminta kepada para penghadap agar membuat surat pernyataan (bermaterai) bahwa tidak datang bersamaan tersebut merupakan kehendak para penghadap/pihak sendiri, dan segala resiko apapun yang muncul di kemudian hari menjadi tanggungjawab para penghadap/para pihak dan pernyataan tersebut djahitkan/dilekatkan pada minuta akta.

Kaitan dalam hal tersebut di atas, jika sesuatu yang ditentukan secara formal dalam UUJN seperti tindakkan menghadap yang tidak datang secara bersamaan, apakah bisa dinegosiasikan dengan membuat surat pernyataan tersebut. Hal tersebut bisa dilakukan dalam arti yaitu:

1. Para penghadap tidak dapat datang pada saat yang sama yang telah ditentukan, dan Notaris mengizinkan untuk melakukan pembacaan dan penandatanganan kepada penghadap yang datang terlebih dahulu, kemudian akan dibacakan kembali kepada setiap yang datang.

2. Tindakan para penghadap yang disebutkan dalam akta dan tidak bersama-sama tersebut terlebih dahulu telah disepakati dan dikonfirmasikan oleh para penghadap sendiri. 
3. Akta seperti ini dibuat pada hari dan tanggal yang sama, hanya jam/pukul yang menghadap berbeda/tidak bersamaan. Jika berbeda hari dan tanggal akan berbenturan dengan akta yang dibuat pada hari dan tanggal berikutnya.

4. Pembacaan dan penandatanganan tersebut tetap dilakukan di hadapan Notaris.

5. Akta Notaris untuk substansi (isi) akta yang sudah pasti yang tidak mungkin dilakukan perubahan lagi. Jika penghadap yang datang berikutnya ingin mengubah, maka harus ada konfirmasi kepada penghadap yang lainnya. Jika tidak dikonfirmasikan tidak perlu dibuat akta tersebut.

6. Akta Notaris seperti tersebut hanya untuk akta pihak (Partij) saja.

7. Jika Notaris membuat akta seperti tersebut di atas, maka tidak bisa disisipi dengan akta atau penghadap lainnya, akta tersebut harus diselesaikan sampai penghadap telah datang semuanya. ${ }^{15}$

Pasal 38 UUJN terutama pada awal akta (pencantuman jam/pukul) menghadap dan akhir akta, pembuatan akta Notaris sebagaimana tersebut di atas dapat dilakukan masih dalam koridor ketentuan Pasal 38 UUJN (harus memuat unsur yang harus ada dalam akta Notaris), yaitu:

1. Pasal 16 ayat (1) huruf m UUJN menyebutkan bahwa, membacakan akta di hadapan penghadap dengan dihadiri oleh paling sedikit 2 orang saksi, atau 4 orang saksi khusus untuk pembuatan akta wasiat di bawah tangan, dan ditandatangani pada saat itu juga oleh penghadap, saksi dan Notaris.

2. Pasal 16 ayat (7) UUJN menyebutkan bahwa, pembacaan sebagaimana dimaksud pada ayat (1) huruf $m$ tidak wajib dilakukan, jika penghadap menghendaki agar akta tidak dibacakan karena penghadap telah membaca sendiri, mengetahui, dan memahami isinya, dengan ketentuan bahwa hal tersebut dinyatakan dalam penutup akta serta pada setiap halaman minuta akta diparaf oleh penghadap, saksi dan Notaris.

3. Ketentuan Pasal 16 ayat (1) huruf m UUJN setelah akta dibacakan di hadapan penghadap dan ditandatangani pada saat itu juga oleh penghadap, saksi dan Notaris. Pengertian atau maksud kalimat ini bisa saja ditafsirkan dilakukan oleh para penghadap bersamaan dalam satu waktu atau para penghadap tidak datang bersamaan dalam waktu yang berbeda. ${ }^{16}$

Notaris jika akan dibuat akta seperti itu tidak perlu merubah apapun pada pada awal akta, penyebutan jam/pukul merupakan waktu saat menghadap untuk penghadap yang pertama datang menghadap, sedangkan penghadap lainnya yang menghadap kemudian akan disebutkan pada bagian akhir akta. Bahwa pembuatan akta seperti ini harus pula disebutkan sebagai kesepakatan para penghadap sehingga pada akhir premisse atau sebelum memasuki isi akta perlu dituliskan kalimat "para penghadap telah saling sepakat dan mengkonfirmasikan bahwa dalam pembuatan akta ini tidak datang secara bersama-sama ke hadapan Notaris, dan kesepakatan serta konfirmasi tersebut menjadi tanggungjawab penghadap sepenuhnya". Hal yang tidak kalah pentingnya yang perlu dilakukan demi mencegah terjadinya pengingkaran oleh penghadap yang tidak datang bersamaan pada saat proses peresmian akta adalah kewajiban penandatanganan

${ }^{15}$ Ibid. 3.

${ }^{16}$ Philipus M. Hadjon, Formulir Pendaftaran Tanah Bukan Akta Otentik, Surabaya Post, Surabaya, 2001, hlm. 
akta disertai fingerprint atau cap sidik jari demi menghindari pemalsuan tanda tangan oleh penghadap. Kebenaran fingerprint inilah yang akan menjadi bukti apabila diperlukan (untuk mitigasi risiko bagi Notaris).

\section{Penutup}

Berdasarkan uraian pembahasan atas terdapat 2 (dua) kesimpulan yakni, pertama pembacaan dan penandatanganan akta yang tidak dilakukan di hadapan Notaris akan berakibat turunnya nilai pembuktian akta otentik menjadi akta di bawah tangan sebagaimana tertuang dalam Pasal 16 ayat (9) UUJN dan melanggar ketentuan Pasal 4 ayat (6) Kode Etik Ikatan Notaris Indonesia yang menimbulkan konsekuensi yakni berupa sanksi yang dikenakan terhadap anggota (dalam hal ini Notaris) yang melakukan pelanggaran kode etik, yakni berupa teguran, peringatan; schorsing (pemecatan sementara) dari keanggotaan perkumpulan, onzetting (pemecatan) dari keanggotaan perkumpulan, pemberhentian dengan tidak hormat dari keanggotaan perkumpulan. Tidak dipenuhinya syarat-syarat yang sudah ditentukan menurut hukum juga dapat menyebabkan akta Notaris menjadi batal demi hukum.

Kedua, mitigasi risiko dalam hal penghadap tidak datang bersama-sama (secara bersamaan), maka Notaris meminta kepada para penghadap agar membuat surat pernyataan (bermaterai) bahwa tidak datang bersama-sama tersebut merupakan kehendak para penghadap/pihak sendiri, dan segala risiko apapun yang muncul di kemudian hari menjadi tanggungjawab para penghadap/para pihak dan pernyataan tersebut dijahitkan/dilekatkan pada minuta akta.

Berdasarkan kesimpulan di atas, terdapat 2 saran yakni, pertama, perlunya peran aktif dari Ikatan Notaris Indonesia dalam bentuk koordinasi terhadap seluruh Notaris, khususnya Notaris yang menjadi rekanan bank agar benar-benar menjalankan tugasnya berdasarkan ketentuan perundang-undangan yang berlaku. Kedua, perlunya bagi lembaga Notaris untuk sama-sama menyumbangkan pemikiran supaya dapat mendapatkan suatu gagasan baru mengenai mitigas risiko terhadap penghadap yang tidak dapat hadir bersama-sama pada saat proses pembacaan dan penandatanganan akta di hadapan Notaris dan gagasan tersebut agar kiranya dapat dituangkan ke dalam suatu peraturan yang dapat diterima oleh semua pihak.

\section{Daftar Pustaka}

\section{Buku}

Anshori, Abdul Ghofur, Lembaga Kenotariatan Indonesia; Perspektif Hukum dan Etika, Cetakan Pertama, Yogyakarta, UII Press, 2009.

Pandoman, Agus, Teori dan Praktik Akta; Perikatan Publisitas dan Non-Publisitas, Cetakan Pertama, Yogyakarta, PT. Raga Utama Kreasi, 2017.

Patton, George Whitecross, A Text-Book of Jurisprudence, Oxford, Clarendon Press, 1953.

Adjie, Habib, Sanksi Perdata dan Administratif Terhadap Notaris Sebagai Pejabat Publik, Bandung, Refika Aditama, 2009.

Soerodjo, Irawan, Kepastian Hukum Hak Atas Tanah di Indonesia, Surabaya, Arkola, 2003. 
Darus, Muhammad Luthfan Hadi, Hukum Notariat dan Tanggungjawab Jabatan Notaris, Cetakan Pertama, Yogyakarta, UII Press, 2017.

Hadjon, Philipus M., Formulir Pendaftaran Tanah Bukan Akta Otentik, Surabaya, Surabaya Post, 2001.

Notosoedirjo, R. Soegondo, Hukum Notariat di Indonesia; Suatu Penjelasan, Jakarta, PT. RajaGrafindo Persada, 1993.

\section{Peraturan Perundang-undangan}

Kitab Undang-Undang Hukum Perdata.

Undang-Undang Nomor 2 Tahun 2014 tentang Perubahan Atas Undang-Undang Nomor 30 Tahun 2004 tentang Jabatan Notaris.

Kode Etik Ikatan Notaris Indonesia. 